\title{
New methods to spatially extend thermal response test assessments
}

\author{
J asmin Raymond \\ Lorenzo Perozzi
}

\author{
Michel Malo \\ Erwan Gloaguen
}

\author{
Louis Lamarche \\ Carl Bégin
}

\begin{abstract}
Thermal response tests (TRTs), used to evaluate the subsurface thermal conductivity when designing ground source heat pump systems, are spatially limited to the vicinity of the borehole where a test is carried out. The subsurface is heterogeneous and the thermal conductivity assessment provided by a TRT is likely to vary beyond the tested borehole. New methods have, therefore, been developed to extend subsurface assessments at the building site and the urban district scales. The first method relies on temperature profiles measured at equilibrium in ground heat exchangers that are reproduced with inverse numerical simulations to infer the terrestrial heat flow and the subsurface thermal conductivity beyond a first TRT. Inversion of temperature profiles was verified at a pilot site in the Appalachians where TRTs had been performed and showed a thermal conductivity estimate within less than $10 \%$ for both approaches. The second method is based on geostatistical simulations to map the distribution of the subsurface thermal conductivity in areas where several ground source heat pump installations are anticipated. A first mapping exercise was achieved to the north of Montreal in the St. Lawrence Lowlands with fours TRTs and ten laboratory measurements interpolated with sequential Gaussian simulations.
\end{abstract}

\section{NTRODUCTI ON}

Conventional thermal response tests (TRTs; Rainieri et al. 2011; Raymond et al. 2011a; Spitler and Gehlin 2015), with heated water circulating in a pilot ground heat exchanger (GHE), have been successfully implemented in the commercial geothermal sector. The method is mostly used to evaluate the subsurface thermal conductivity when designing ground-coupled heat pump (GCHP) systems.

The subsurface assessment is spatially limited to a single pilot GHE commonly drilled before the installation of the complete GCHP system. The test radius of influence is on the order of 1-2 m (3.3-6.6 ft; Raymond and Lamarche 2014a), while GCHP systems installed in the commercial sector can enclose tens of boreholes covering hundreds of squared meters where subsurface conditions are likely non-uniform. TRTs have additionally been unable to penetrate the residential geothermal sector, where drilling of a pilot GHE before the installation of a GCHP system enclosing few, likely less than ten, boreholes is uneconomical. Life-cycle cost analysis of GCHP systems has, in fact, shown that a TRT can be uneconomical for small buildings (Robert and Gosselin 2014).

Research with the objective to spatially extend assessments provided by TRT has therefore been carried out to develop new methods for evaluating the subsurface thermal conductivity distribution at the building site and the urban district scales. The methods do not replace TRTs but allows extending the subsurface thermal conductivity assessment as an alternative to repeating TRTs. The first application developed relies on inverse numerical modeling

Jasmin Raymond (jasmin.raymond@inrs.ca), Michel Malo and Erwan Gloaguen are professors at Institut national de la recherche scientifique, Louis Lamarche is a professor at École de Technologie Supérieure, Lorenzo Perozzi is a postdoctoral fellow at Institut national de la recheche scientifique and Carl Bégin is an engineer at Marmott Energies. 
of temperature profiles and can be used at the site scale for large projects where tens of GHEs are installed on the same site. The second application is based on geostatistical simulations and can be used at the district scale where several small GCHP systems are planned to be installed in a given geological region. Both methods, which have been developed in the Appalachians and the St. Lawrence Lowlands geological provinces of Canada, are presented with respect to the scale at which they provide extension of subsurface thermal conductivity assessments.

\section{BUI LDI NG SITE SCALE METHOD}

The method to extend TRT assessments at the building site scale can is to infer subsurface thermal conductivity changes in a field where many GHEs could be installed. A single TRT performed in a first GHE and temperature profiles measured in additional boreholes offer the observations to be reproduced with inverse numerical simulations aiming at identifying the terrestrial heat flow and, then, the subsurface thermal conductivity beyond the first GHE at the additional boreholes.

As a first step, the subsurface thermal conductivity is evaluated with a conventional TRT in a pilot GHE installed before the complete GHE field. A temperature profile undisturbed by the TRT and in equilibrium with the subsurface is additionally measured in the GHE. This can be done with a wired probe lowered in a pipe of the GHE. Upon lowering the probe, the water level in the GHE pipe rises and the depth-temperature measurements have to be corrected to adequately evaluate the vertical geothermal gradient along the borehole. This is achieved by subtracting the water level rise due to the probe and the wire volume to the depth measured with the pressure transducer.

Transient numerical simulations of heat transfer in the subsurface are performed to reproduce the temperature profile of the pilot GHE affected by climate warming at the surface and to identify the terrestrial heat flow at the site. In other words, climate changes that occurred over the past centuries are considered as a thermal perturbation in heat tracing simulations to reproduce the temperature signal of the subsurface. The model used for simulations can be unidimensional in the case of a flat surface or bi- or three-dimensional for sites with topographic variations. A 2D model with a surface slope was used for a first example (Figure 1a). Conductive heat transfer was solved numerically with the finite element method using the program Comsol Multiphysics (COMSOL AB 2011):

$$
\frac{\partial}{\partial x}\left(\lambda \frac{\partial T}{\partial x}\right)+\frac{\partial}{\partial z}\left(\lambda \frac{\partial T}{\partial z}\right)=\rho c \frac{\partial T}{\partial t}
$$

where the medium thermal conductivity $\lambda\left[\mathrm{M} \mathrm{L} \mathrm{t}^{-3} \mathrm{~T}^{-1}\right]$ is assumed to be isotropic, $\varrho\left[\mathrm{M} \mathrm{L}^{-3}\right]$ is the density and $c\left[\mathrm{~L}^{2} \mathrm{t}^{-2} \mathrm{~T}^{-1}\right]$ is the specific heat capacity. Heat generation due to the decay of radioactive elements inside the subsurface was neglected. The model boundaries were an imposed temperature at the surface varying with time to reproduce the paleoclimatic changes in ground surface temperature that occurred over the past six centuries (Beltrami et al. 2003), a constant heat flux at the bottom and adiabatic vertical side walls. The temperature values at the upper boundary, defined in the model with a step function (Figure 1b), were selected according to previous studies aiming to reconstruct the ground paleoclimate history in a proximal region with deeper boreholes (Chouinard and Mareschal 2007). The thermal conductivity measured with the TRT in the pilot GHE and the estimated volumetric heat capacity associated to the rock type were imposed to the subsurface for the simulations conducted for a period of $615 \mathrm{y}$ preceding the measurement of the temperature profile. The initial temperature condition was calculated from the equilibrium geothermal gradient according to the surface thermal conductivity and the basal heat flow, which is unknown. A derivative-free solver (Conn et al. 2009) was used to minimize the sum of squared residuals calculated from the differences between measured and simulated temperatures to find the basal heat flow. This information is essential to continue to the next step and infer the subsurface thermal conductivity at the location of other GHEs. 


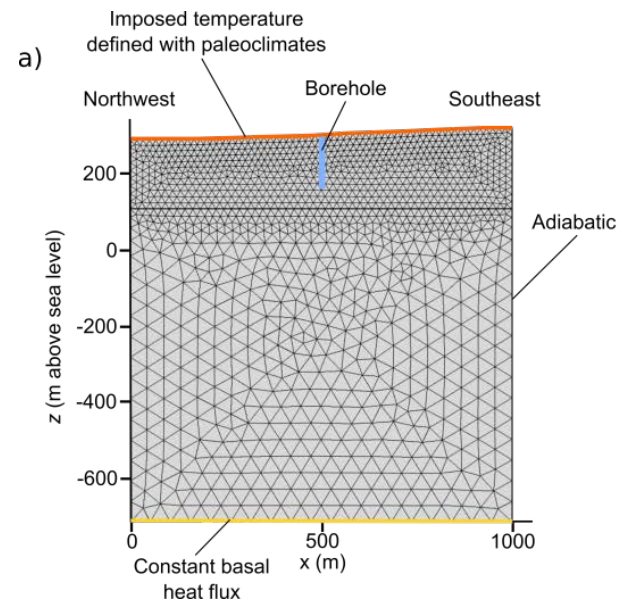

b)

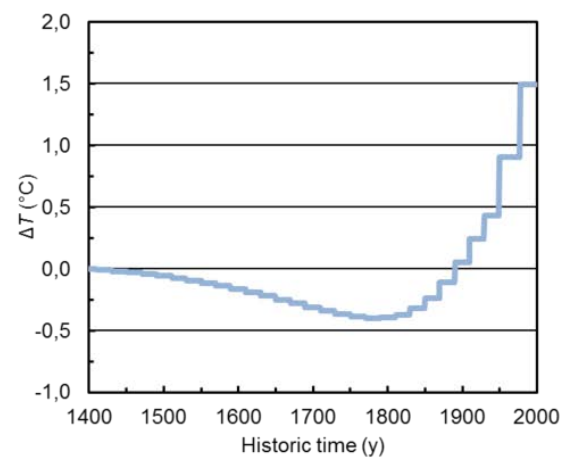

Figure 1 a) Model geometry, mesh and boundaries used for inverse numerical simulations taking into account the b) paleoclimatic changes in ground surface temperature to infer the terrestrial heat flow and, then, the subsurface thermal conductivity by reproducing temperature profiles (Raymond et al. 2016).

Temperature profiles are measured in other GHEs of the same building site for the second step. This can be done again with a wired probe, in additional pilot GHEs or when the complete GHE field of a GCHP system is installed to verify if there are important subsurface thermal conductivity changes that could affect the initial design plans.

Similar numerical simulations are carried out to reproduce the temperature profiles in equilibrium with the subsurface. The model remains unchanged except that the basal heat flow identified in the first step is imposed at the bottom boundary and the subsurface thermal conductivity is considered as the unknown to be identified by the solver. The objective function of the solver is to minimize the sum of squared residuals between observed and simulated temperatures to find the subsurface thermal conductivity at the location of additional GHEs. The temperature profiles are sufficient to extent the subsurface thermal conductivity assessment of the first GHE without repeating TRTs in each GHE. The method is limited to building sites or regions with similar terrestrial heat flow and surface land use history affecting the ground surface temperature evolution.

\section{URBAN DISTRICT SCALE METHOD}

The method to extend TRT assessments with geostatistical simulations is to map the subsurface thermal conductivity distribution in an area where GCHP installations are anticipated, likely an urban district with many buildings having the potential to host geothermal systems. The subsurface thermal conductivity is initially determined in situ with TRTs at building sites using ongoing installations and combined with laboratory analysis of thermal conductivity of rock samples collected in surface outcrops to finally simulate the thermal conductivity distribution of the host rock at a shallow depth with stochastic methods constrained from the surface geological map.

In the following example, TRTs were performed with a heating cable inserted into GHEs of residential systems to minimize disturbance to the occupants (Raymond et al. 2011b, 2010). The GHE were approximately $45 \mathrm{~m}$ (147.6 ft) depth, which allowed using a continuous heating cable with a power source fewer than $1200 \mathrm{~W}$ (4095 Btu hr-1). Heat was injected during 50-55 h followed by the monitoring of the thermal recovery period during 60-72 h. The temperature signals measured by fifteen submersible temperature loggers located along the heating cable inside a GHE pipe were analyzed with the infinite line-source equation to find the subsurface thermal conductivity at 
depth based on recovery measurements using the slope method (Pehme et al. 2007):

$$
m \approx \frac{\Delta T}{\Delta \ln \left(t / t_{\mathrm{c}}\right)} \approx \frac{q}{4 \pi \lambda}
$$

where $q\left[\mathrm{M} \mathrm{L} \mathrm{t}^{-3}\right]$ is the heat injection rate per unit length of heating cable and $m[\mathrm{~T}]$ is the slope determined from the late temperature increments $\Delta T$ plotted as function of the normalized logarithmic time $t / t_{\mathrm{c}}$. The analysis of recovery data, where $t_{\mathrm{c}}$ is the time after the heat injection stopped, helps to decrease the effect of power fluctuations and cable movements (Raymond et al. 2011b). The time normalization originates from the application of the superposition principle to the infinite line-source equation to reproduce the thermal recovery. The fifteen thermal conductivity evaluations obtained for each GHE with temperature signals at depth were averaged to find the global thermal conductivity of the host rock over $45 \mathrm{~m}$ depth, removing upper values inferred in the overburden. Such in situ measurements provide data points to interpolate with geostatistical simulations in a further step.

Laboratory analyses of rock samples collected in outcrops are additionally performed to complement the in situ data set. The rock samples are collected in representative outcrops of the study area. The modified transient plane source (TPS) method (Harris et al. 2014) was used in the laboratory for the case presented below. Samples were cut and saturated with water to apply the heat source on a flat surface that is heated to determine the thermal conductivity of the rock. The laboratory analyses are fast to achieve when compared to in situ assessments, which allowed increasing the amount of data points available for geostatistical simulations.

The interpolation of host rock thermal conductivity was achieved with sequential Gaussian simulations (SGS; Goovaerts 1997). A grid is initially drawn over the study area and cells with known thermal conductivity from in situ and laboratory measurements are considered static. A new cell is then selected at random. The Gaussian probability density function at the new cell is obtained by kriging from the measured values and the previously simulated values along the random path (Figure 2). This feedback loop, which retains previously simulated values as extra data points, is the key to ensure that the simulations are spatially correlated. This process is repeated until all the grid cells are visited once. Multiple simulations are generated by using different random paths and random seeds. Independent realizations of equivalent probability are combined to calculate the mean and the standard deviation defining the uncertainty. The final result obtained is a map showing the distribution of the host rock thermal conductivity and its uncertainty for a shallow depth up to $45 \mathrm{~m}$, which can be used to design new GSHP systems without repeating TRTs.
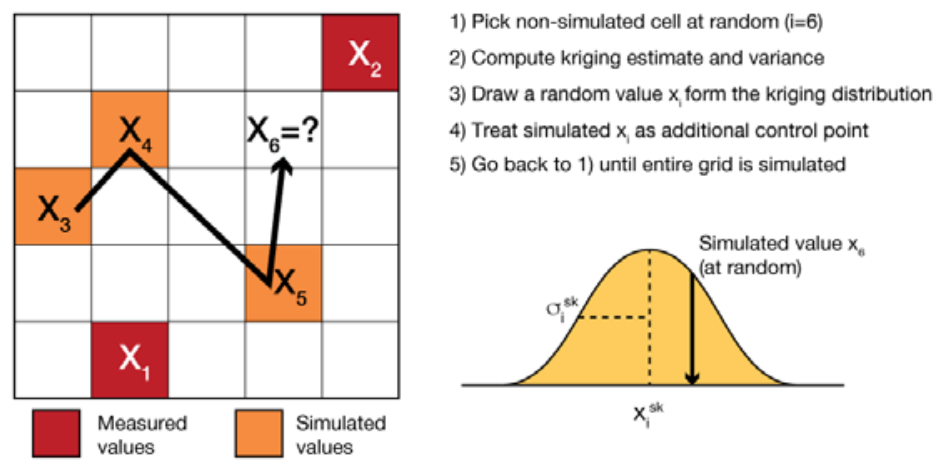

Figure 2 Schematic illustration of the SGS algorithm used to simulate the distribution of host rock thermal conductivity (Perozzi et al. 2016).

\section{RESULTS - BUI LDI NG SITE SCALE METHOD}

The numerical modeling method to inverse temperature profiles was used at a pilot site in Saint-Lazard-de- 
Bellechasse where two conventional TRTs had been performed previously (Raymond et al. 2016). The GHEs had a

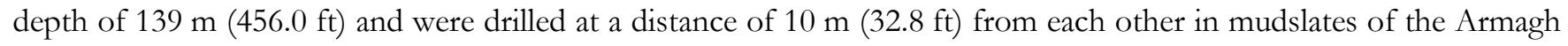
Formation in the Appalachians (Lebel and Hubert 1995). Results from the first TRT, indicating a subsurface thermal conductivity equal to $3.0 \mathrm{~W} \mathrm{~m}^{-1} \mathrm{~K}^{-1}\left(1.73 \mathrm{Btu} \mathrm{hr}^{-1} \mathrm{ft}^{-1}{ }^{\circ} \mathrm{F}^{-1}\right)$, was used to find the site basal heat flow and that from the second TRT, indicating a subsurface thermal conductivity equal to $3.5 \mathrm{~W} \mathrm{~m}^{-1} \mathrm{~K}^{-1}\left(2.02 \mathrm{Btu} \mathrm{hr}^{-1} \mathrm{ft}^{-1}{ }^{\circ} \mathrm{F}^{-1}\right)$, was used to verify the inverse numerical modeling method.

The temperature profile measured in each GHE showed an inverse geothermal gradient near the surface that is characteristic of climate warming (Figure 3). On top of that temperature signal, seasonal temperature variations can be detected in each GHE and a groundwater flow perturbation is present in the second GHE. Numerical simulations did not consider these phenomena and simulations, therefore, aimed at reproducing the bottom $\sim 100$ to $120 \mathrm{~m}$ of the temperature profiles. Numerical simulations were first conducted to invert the temperature profile of the first GHE to find the site basal heat flow (Figure 3a). The minimum and maximum bounds for the basal heat flow optimization were 20 and $50 \mathrm{~mW} \mathrm{~m}-2\left(6.3\right.$ and $\left.15.8 \times 10^{-3} \mathrm{Btu} \mathrm{hr}^{-1} \mathrm{ft}^{-2}\right)$ determined from a heat flow map (Majorowicz and Grasby 2010) and the optimization started at the lower bound. Twenty-five iterations were necessary for the solver using the coordinate search method to converge toward a solution that decreased the sum of the squared residuals from $\sim 13$ to $9.3 \times 10^{-2}$ for the best fit scenario, indicating a basal heat flow toward $25 \mathrm{~mW} \mathrm{~m}-2\left(7.9 \times 10^{-3} \mathrm{Btu} \mathrm{hr}^{-1} \mathrm{ft}^{-2}\right)$. The initial temperature condition for the best fit scenario was a temperature gradient equal to $8.3 \times 10^{-3}{ }^{\circ} \mathrm{C} \mathrm{m}^{-1}$ $\left(4.6 \times 10^{-3}{ }^{\circ} \mathrm{F} \mathrm{ft}^{-1}\right)$.
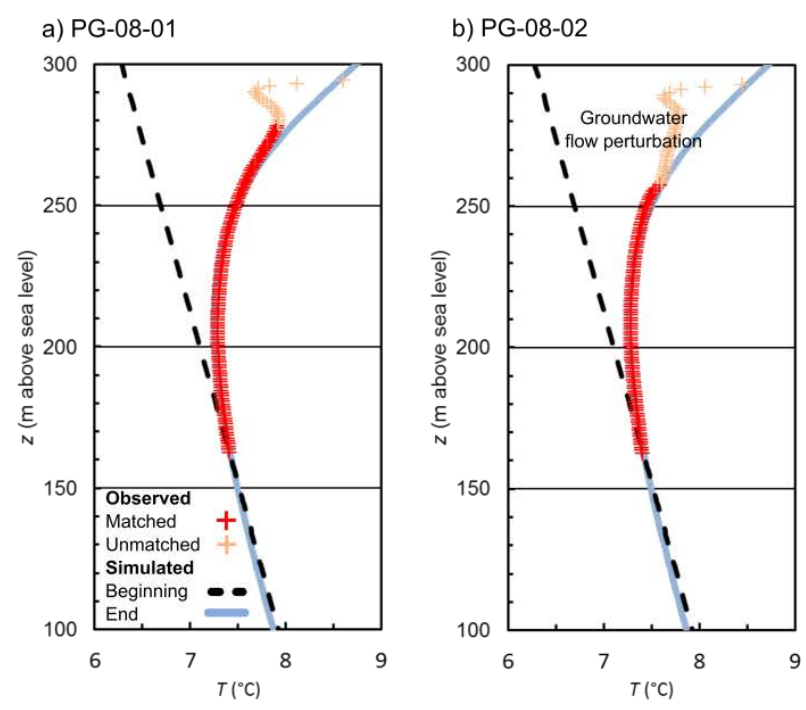

c) Localization

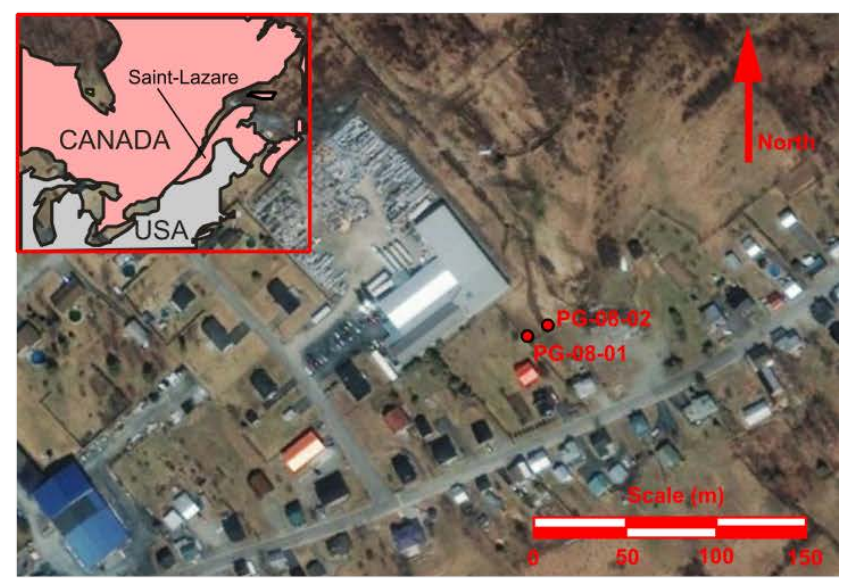

Figure 3 Observed and simulated temperature profiles in GHE number a) PG-08-01 and b) PG-08-02 at c) SaintLazare-de-Bellechasse. The two GHE are located $10 \mathrm{~m}(32.8 \mathrm{ft})$ from each other.

Subsequent simulations were computed to invert the temperature profile of the second GHE to find the subsurface thermal conductivity at this location (Figure 3b). The minimum and maximum bounds for the optimization process were a subsurface thermal conductivity equal to 2.8 and $4.2 \mathrm{~W} \mathrm{~m}^{-1} \mathrm{~K}^{-1}(1.62$ and $\left.2.43 \mathrm{Btu} \mathrm{hr}^{-1} \mathrm{ft}^{-1}{ }^{\circ} \mathrm{F}^{-1}\right)$ and the optimization started at the lower bound. Twenty-four iterations were necessary for the coordinate search solver to converge toward a solution that decreased the sum of squared residuals from $2.5 \times 10^{-1}$ to $2.5 \times 10^{-2}$, indicating subsurface thermal conductivity converging toward $3.2 \mathrm{~W} \mathrm{~m}^{-1} \mathrm{~K}^{-1}\left(1.85 \mathrm{Btu} \mathrm{hr}^{-1} \mathrm{ft}^{-1}{ }^{\circ} \mathrm{F}^{-1}\right)$. The 
initial temperature condition for the best fit scenario was a temperature gradient equal to $7.8 \times 10^{-3}{ }^{\circ} \mathrm{C} \mathrm{m}^{-1}$ $\left(4.3 \times 10^{-3}{ }^{\circ} \mathrm{F} \mathrm{ft}^{-1}\right)$. The thermal conductivity value obtained from inverse numerical modeling was within less than $10 \%$ to that measured with the TRT, which demonstrates the use of the method. Inversion of temperature profiles is not expected to be as accurate as TRT because of the uncertainty of temperature changes due to paleoclimates and the basal heat flow to impose at the model boundaries but appears to be sufficiently accurate to identify lateral subsurface thermal conductivity changes at the building site scale.

\section{RESULTS - URBAN DISTRICT SCALE METHOD}

The geostatistical method to interpolate the host rock thermal conductivity was used in a $35 \mathrm{~km}^{2}$ (8649 acres) region to the north of Montreal in the St. Lawrence Lowlands geological province (Figure 4a; Perozzi et al. 2016), constituted of non-deformed Cambro-Ordovician sedimentary sequences (Globensky 1987). The area was divided in 35000 cells, each covering $100 \times 100 \mathrm{~m}(328 \times 328 \mathrm{ft})$. Four data points from in situ measurements were acquired with TRTs in boreholes that intercept the Trenton, Black River and Chazy geological groups, as well as the Beauharnois Formation, indicating a thermal conductivity ranging from 2.4 to $4.2 \mathrm{~W} \mathrm{~m}^{-1} \mathrm{~K}^{-1}$ (1.39 to 2.43 Btu hr-1 $\mathrm{ft}^{-1}{ }^{\circ} \mathrm{F}^{-1}$; Table 1). The highest value was associated to the Beauharnois Formation with greater dolomite content while the Trenton, Black River and Chazy groups are mostly argillaceous limestones with a lower thermal conductivity. Ten outcrops samples were collected in those three groups for additional data points and laboratory analysis indicated a thermal conductivity ranging from 2.1 to $3.5 \mathrm{~W} \mathrm{~m}^{-1} \mathrm{~K}^{-1}\left(1.21\right.$ to $2.02 \mathrm{Btu} \mathrm{hr}^{-1} \mathrm{ft}^{-1}{ }^{\circ} \mathrm{F}^{-1}$; Table 1$)$. The in situ assessment and the laboratory analysis were complemented by twenty-seven synthetic data points to increase the spatial resolution and for the simulations to better reflect the geological setting. The synthetic data points were determined from the work of Nasr et al. (2015) and Sirois et al. (2015) that defined thermostratigraphic units in the St. Lawrence Lowlands with forty-five laboratory measurements of thermal conductivity, representing the complete sedimentary sequence and covering the entire sedimentary basin. The average thermal conductivity value specified for the synthetic data points of the Trenton, Black River and Chazy groups was $2.67 \mathrm{~W} \mathrm{~m}^{-1} \mathrm{~K}^{-1}(1.54$ Btu $\left.\mathrm{hr}^{-1} \mathrm{ft}^{-1}{ }^{\circ} \mathrm{F}^{-1}\right)$ and that of the Beauharnois Formation was $3.40 \mathrm{~W} \mathrm{~m}^{-1} \mathrm{~K}^{-1}\left(1.96 \mathrm{Btu} \mathrm{hr}^{-1} \mathrm{ft}^{-1}{ }^{\circ} \mathrm{F}^{-1}\right)$.

A total of ten independent SGS realizations (Figure 4b) were computed to map the thermal conductivity distribution of the host rock and combined to define an average realization (Figure 4c), with its standard deviation (Figure 4d) to evaluate the uncertainty of the simulated values. The thermal conductivity distribution reflects the geological map with values above $3.0 \mathrm{~W} \mathrm{~m}^{-1} \mathrm{~K}^{-1}\left(1.73 \mathrm{Btu} \mathrm{hr}^{-1} \mathrm{ft}^{-1}{ }^{\circ} \mathrm{F}-1\right)$ in the upper left corner of the study associated to the Beauharnois Formation, while values below $3.0 \mathrm{~W} \mathrm{~m}^{-1} \mathrm{~K}^{-1}\left(1.73 \mathrm{Btu} \mathrm{hr}^{-1} \mathrm{ft}^{-1}{ }^{\circ} \mathrm{F}-1\right)$ are dominantly associated to the Trenton, Black River and Chazy groups. The standard deviation of the realizations suggests an uncertainty of less than $0.5 \mathrm{~W} \mathrm{~m}^{-1} \mathrm{~K}^{-1}\left(0.29 \mathrm{Btu} \mathrm{hr}^{-1} \mathrm{ft}^{-1}{ }^{\circ} \mathrm{F}^{-1}\right)$ for the central region of the study area including most of the measured data points. Again, this method is not expected to be as accurate as TRTs because local subsurface heterogeneity can be difficult to sample, especially in urban areas with few outcrops, such that the map may not picture site scale heterogeneity. Nevertheless, the map is believed to be a useful tool to design small GCHP systems with low uncertainty in GHE length and avoid repeating TRTs at each building site. Screening design calculations can be achieved with the map data for large GCHP systems and a TRT may be performed afterward to validate design and reduce GHE length uncertainty. 
Table 1. Thermal conductivity measurements used for geostatistical simulations

\begin{tabular}{|c|c|c|c|c|}
\hline $\begin{array}{l}\text { Latitude } \\
\text { UTM }\end{array}$ & $\begin{array}{l}\text { Longitude } \\
\text { NAD } 83\end{array}$ & $\begin{array}{c}\text { Thermal conductivity } \\
\mathrm{W} \mathrm{m}^{-1} \mathrm{~K}^{-1} / \mathrm{Btu} \mathrm{hr}^{-1} \mathrm{ft}^{-1}{ }^{\circ} \mathrm{F}^{-1}\end{array}$ & Method & Thermostratigraphic unit \\
\hline 45.519249 & $\begin{array}{l}-73.652824 \\
\end{array}$ & "2.10/1.21 & Laboratory: TPS & "Trenton, Black River, Chazy \\
\hline 45.519249 & -73.652824 & $2.22 / 1.29$ & Laboratory : TPS & Trenton, Black River, Chazy \\
\hline 45.547637 & -73.696752 & $2.90 / 1.68$ & Laboratory : TPS & Trenton, Black River, Chazy \\
\hline 45.603070 & -73.656963 & $2.90 / 1.68$ & Laboratory : TPS & Trenton, Black River, Chazy \\
\hline 45.604803 & -73.659649 & $3.15 / 1.82$ & Laboratory : TPS & Trenton, Black River, Chazy \\
\hline 45.605735 & -73.661411 & $2.31 / 1.36$ & Laboratory : TPS & Trenton, Black River, Chazy \\
\hline 45.603070 & -73.656963 & $2.60 / 1.50$ & Laboratory : TPS & Trenton, Black River, Chazy \\
\hline 45.602381 & -73.658056 & $2.93 / 1.69$ & Laboratory : TPS & Trenton, Black River, Chazy \\
\hline 45.509640 & -73.627682 & $2.24 / 1.30$ & Laboratory : TPS & Trenton, Black River, Chazy \\
\hline 45.604803 & -73.659649 & $2.16 / 1.25$ & Laboratory : TPS & Trenton, Black River, Chazv \\
\hline 45.511454 & -73.651800 & $2.39 / 1.38$ & Field : TRT & Trenton, Black River, Chazy \\
\hline 45.504581 & -73.657720 & $2.39 / 1.38$ & Field : TRT & Trenton, Black River, Chazy \\
\hline 45.516988 & -73.648486 & $2.81 / 1.62$ & Field : TRT & Trenton, Black River, Chazy \\
\hline 45.527392 & -73.855424 & $4.20 / 2.43$ & Field : TRT & Beauharnois \\
\hline
\end{tabular}
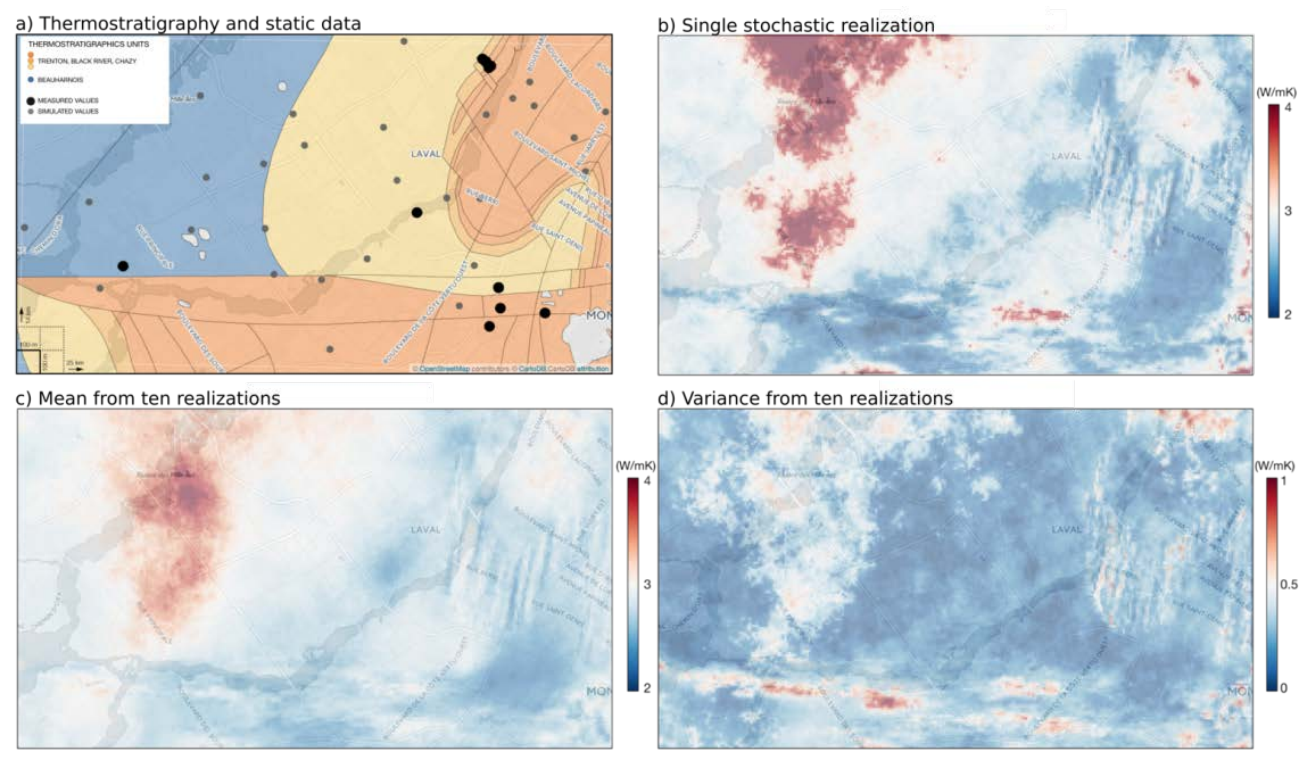

Figure 4 Sequential Gaussian simulations of the host rock thermal conductivity north of Montreal (Perozzi et al. 2016).

\section{DISCUSSION AND CONCLUSIONS}

Since the development of the first thermal response test (TRT) concept (Mogensen 1983) and the successful deployment of mobile apparatus (Austin III 1998; Gehlin 1998), research to evaluate the subsurface thermal conductivity in the context of ground source heat pump (GCHP) design has mostly focused on improving field and analytical aspects of the TRT method. Field improvements included the development of TRT units with power regulations to decrease fluctuations in heat injection rate (Witte et al. 2002), downhole temperature measurements with optical fibers (Acuña and Palm 2013; Acuña et al. 2011; Fujii et al. 2009, 2006) and wireless sensors (Martos et al. 2011; Rohner et al. 2005), as well as the use of a heating cable to avoid water circulation and reduce the power requirement (Raymond et al. 2015, 2010; Raymond and Lamarche 2014b). The test analysis has been improved to take 
into account groundwater flow (Raymond et al. 2011c; Signorelli et al. 2007; Wagner et al. 2013), thermal recovery (Raymond et al. 2011a, 2011b), variable heat injection rates (Beier and Smith 2003), parameter estimation (Choi and Ooka 2015; Wagner and Clauser 2005) and uncertainty (Witte 2013). The research presented in this manuscript is to address an additional problematic related to the spatial limitation of TRT. It is recognized that heat injection tests carried in a borehole have a limited radius of influence and that the subsurface is non-uniform. New methods to extend TRT assessments beyond a single ground heat exchanger (GHE) can, therefore, benefit to complex GCHP design. The concepts presented are indirect methods to evaluate changes in subsurface thermal conductivity at the building site and the urban district scale. This work is some of the first attempts to inverse temperature profiles to infer the subsurface thermal conductivity beyond a first TRT and map the distribution of the subsurface thermal conductivity with geostatistical simulations.

The first example was to verify the inverse numerical modeling approach at a pilot site in the Appalachians. Results obtained with preliminary simulations presented here highlight the potential of the method that could be improved to simulate groundwater flow and better reproduce the observed temperature signal affected by advective heat transfer. The second example was achieved in a populated region of the St. Lawrence Lowlands to the north of Montreal, where the installation of residential GSHP systems is planned. It was possible to perform TRTs at ongoing residential sites and extent the subsurface thermal conductivity assessments beyond the sites for the upcoming installations. The test costs are distributed over several installations, opening new markets for TRTs, such as the residential geothermal sector. More field data is needed to continue this study by validating the thermal conductivity distribution map with additional TRT to be performed at upcoming installations. Additional data could further be used with different geostatistical simulation scenarios to recommend a minimum density of field data providing reliable prediction of the host rock thermal conductivity.

Both the inverse numerical modeling and the geostatistical methods were used independently to address a common problematic in the current study but could be combined in future work. At the building site scale, when many temperature profiles are collected to infer the subsurface thermal conductivity, geostatistical simulations can be used to infer the thermal conductivity between the extremities of a GHE field. At the urban district scale, the inversion of temperature profiles can provide a low-cost method to evaluate the subsurface thermal conductivity and add static data points to improve geostatistical simulations. While the TRT field and analytical methods are getting more complete and advance, such ideas can help to reduce the spatial limitation of the TRT, one of the next challenges to address with scientific research.

\section{ACKNOWLEDGMENTS}

The Banting Postdoctoral Fellowship program and the Natural Sciences and Engineering Research Council of Canada are acknowledged for funding this research. The participation of Versaprofiles and Marmott Energies are also recognized for a great contribution to this project.

\section{NOMENCLATURE}

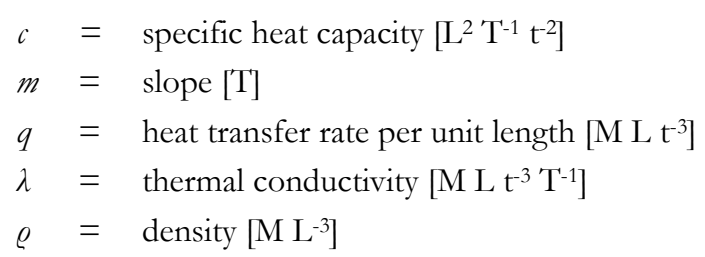

\section{Subscript}

$\mathrm{c} \quad=$ cooling

[L M T t] are used to denote units of length, mass, temperature and time, respectively 


\section{REFERENCES}

Acuña, J., P. Mogensen and B. Palm. 2011. Distributed Thermal Response Tests on a Multi-Pipe Coaxial Borehole Heat Exchanger. HVAC\&R Research 17(6): 1012-29. doi:10.1080/10789669.2011.625304.

Acuña, J. and B. Palm. 2013. Distributed Thermal Response Tests on Pipe-in-Pipe Borehole Heat Exchangers. Applied Energy 109: 312-20. doi:10.1016/j.apenergy.2013.01.024.

Austin III, W.A. 1998. Development of an in Situ System for Measuring Ground Thermal Properties. Oklahoma, USA: Master Thesis, Oklahoma State University.

Beier, R.A. and M.D. Smith. 2003. Removing Variable Heat Rate Effects from Borehole Tests. ASHRAE Transactions 109(2): 46374.

Beltrami, H., C. Gosselin and J. C. Mareschal. 2003. Ground Surface Temperatures in Canada: Spatial and Temporal Variability. Geophysical Research Letters 30: 6.1-6.4. doi:10.1029/2003GL017144.

Choi, W. and R. Ooka. 2015. Interpretation of Disturbed Data in Thermal Response Tests Using the Infinite Line Source Model and Numerical Parameter Estimation Method. Applied Energy 148: 476-88. doi:10.1016/j.apenergy.2015.03.097.

Chouinard, C. and J.-C. Mareschal. 2007. Selection of Borehole Temperature Depth Profiles for Regional Climate Reconstructions. Climate of the Past 3(2): 297-313. doi:10.5194/cp-3-297-2007.

COMSOL AB. 2011. COMSOL Multiphysics User's Guide, Version 4.2. Stockholm, Sweden.

Conn, A.R., K. Scheinberg and L.N. Vicente. 2009. Introduction to Derivative-Free Optimization. Philadelphia, USA: SIAM, MPS-SIAM Series on Optimization.

Fujii, H., H. Okubo and R. Itoi. 2006. Thermal Response Tests Using Optical Fiber Thermometers. GRC Transactions 30: 545-51.

Fujii, H., H. Okubo, K. Nishi, R. Itoi, K. Ohyama and K. Shibata. 2009. An Improved Thermal Response Test for U-Tube Ground Heat Exchanger Based on Optical Fiber Thermometers. Geothermics 38 (4): 399-406. doi:10.1016/j.geothermics.2009.06.002.

Gehlin, S. 1998. Thermal Response Test - in-Situ Measurements of Thermal Properties in Hard Rock. Luleå, Sweden: Licentiate Thesis, Luleå University of Technology, Division of Water Resources Engineering, Department of Environmental Engineering.

Globensky, Y. 1987. Géologie Des Basses-Terres Du Saint-Laurent. Québec, Canada: Ministère de l'Énergie et des Ressources du Québec, MM 85-02.

Goovaerts, P. 1997. Geostatistics for Natural Resources Evaluation. New York, USA: Oxford University Press.

Harris, A., S. Kazachenko, R. Bateman, J. Nickerson and M. Emanuel. 2014. .Measuring the Thermal Conductivity of Heat Transfer Fluids via the Modified Transient Plane Source (MTPS). Journal of Thermal Analysis and Calorimetry 116(3): 1309_ 14. doi:10.1007/s10973-014-3811-6.

Lebel, D and C Hubert. 1995. Géologie de La Région de St-Malachie (Chaudière-Appalaches). Québec, Canada: Gouvernement du Québec, Ministère des Ressources naturelles, Secteur des mines, ET-93-03.

Majorowicz, J.A. and S.E. Grasby. 2010. Heat Flow, Depth-Temperature Variations and Stored Thermal Energy for Enhanced Geothermal Systems in Canada. Journal of Geophysics and Engineering 7(3): 232-41. dx.doi.org/10.1088/17422132/7/3/002.

Martos, J., Á. Montero, J. Torres, J. Soret, G. Martínez and R. García-Olcina. 2011. Novel Wireless Sensor System for Dynamic Characterization of Borehole Heat Exchangers. Sensors 11(7): 7082-94. doi:10.3390/s110707082.

Mogensen, P. 1983. Fluid to Duct Wall Heat Transfer in Duct System Heat Storages. International Conference on Subsurface Heat Storage in Theory and Practice, Appendix, Part II, Stockholm, Sweden: 652-57.

Nasr, M., J. Raymond, and M. Malo. 2015. Évaluation En Laboratoire Des Caractéristiques Thermiques Du Bassin Sédimentaire Des Basses-Terres Du Saint-Laurent. 68th Canadian Geotechnical Conference and 7th Canadian Permafrost Conference, Québec City Canada: 8p.

Pehme, P. E., J. P. Greenhouse and B. L. Parker. 2007. The Active Line Source Temperature Logging Technique and Its Application in Fractured Rock Hydrogeology. Journal of Environmental and Engineering Geophysics 12(4): 307-22. doi:10.2113/jeeg12.4.307.

Perozzi, L., J. Raymond, S. Asselin, E. Gloaguen, M. Malo and C. Bégin. 2016. Simulation géostatistique de la conductivité thermique: Application à une région de La communauté métropolitaine de montréal. Quebec City, Canada: Institut national de la recherche scientifique - Centre Eau Terre Environnement, R1663, http://espace.inrs.ca/3374/1/R001663.pdf.

Rainieri, S., F. Bozzoli and G. Pagliarini. 2011. Modeling Approaches Applied to the Thermal Response Test: A Critical Review of the Literature. HVAC\&R Research 17(6): 977-90. doi:10.1080/10789669.2011.610282. 
Raymond, J. and L. Lamarche. 2014a. Quality Control Assessment of Vertical Ground Heat Exchangers. ASHRAE Transactions 120(2): SE-14-014.

Raymond, J. and L. Lamarche. 2014b. Development and Numerical Validation of a Novel Thermal Response Test with a Low Power Source. Geothermics 51: 434-44. doi:10.1016/j.geothermics.2014.02.004.

Raymond, J., L. Lamarche and M. Malo. 2015. Field Demonstration of a First Thermal Response Test with a Low Power Source. Applied Energy 147: 30-39. doi:10.1016/j.apenergy.2015.01.117.

Raymond, J., L. Lamarche and M. Malo. 2016. Extending Thermal Response Test Assessments with Inverse Numerical Modeling of Temperature Profiles Measured in Ground Heat Exchangers. Renewable Energy 99: 614-21. doi:10.1016/j.renene.2016.07.005.

Raymond, J., G. Robert, R. Therrien and L. Gosselin. 2010. A Novel Thermal Response Test Using Heating Cables. Proceedings of the World Geothermal Congress, Bali, Indonesia: 8p.

Raymond, J., R. Therrien, L. Gosselin and R. Lefebvre. 2011a. A Review of Thermal Response Test Analysis Using Pumping Test Concepts. Ground Water 49(6): 932-45. doi:10.1111/j.1745-6584.2010.00791x.

Raymond, J., R. Therrien and L. Gosselin. 2011b. Borehole Temperature Evolution during Thermal Response Tests. Geothermics 40(1): 69-78. doi:10.1016/i.geothermics.2010.12.002.

Raymond, J., R. Therrien, L. Gosselin and R. Lefebvre. 2011c. Numerical Analysis of Thermal Response Tests with a Groundwater Flow and Heat Transfer Model. Renewable Energy 36(1): 315-24. doi:10.1016/j.renene.2010.06.044.

Robert, F. and L. Gosselin. 2014. New Methodology to Design Ground Coupled Heat Pump Systems Based on Total Cost Minimization. Applied Thermal Engineering 62(2): 481-91. doi:10.1016/j.applthermaleng.2013.08.003.

Rohner, E., L. Rybach and U. Schärli. 2005. A New, Small, Wireless Instrument to Determine Ground Thermal Conductivity in-Situ for Borehole Heat Exchanger Design. Proceedings of the World Geothermal Congress, Antalya, Turkey: 4 p.

Signorelli, S., S. Bassetti, D. Pahud and T. Kohl. 2007. Numerical Evaluation of Thermal Response Tests. Geothermics 36 (2): 141-66. doi:10.1016/j.geothermics.2006.10.006.

Sirois, C., J. Raymond, M. Nasr and M. Malo. 2015. Mapping the Geoexchange Potential of the St. Lawrence Lowlands from Thermal Conductivity Measurements of Rock Samples. AGU-GAC-MAC Joint Assembly, Montreal, Canada.

Spitler, J. D. and S. E.A. Gehlin. 2015. Thermal Response Testing for Ground Source Heat Pump systems-An Historical Review. Renewable and Sustainable Energy Reviews 50: 1125-37. doi:10.1016/j.rser.2015.05.061.

Wagner, R. and C. Clauser. 2005. Evaluating Thermal Response Tests Using Parameter Estimation for Thermal Conductivity and Thermal Capacity. Journal of Geophysics and Engineering 2(4): 349-56.

Wagner, V., P. Blum, M. Kübert and P. Bayer. 2013. Analytical Approach to Groundwater-Influenced Thermal Response Tests of Grouted Borehole Heat Exchangers. Geothermics 46: 22-31. doi:10.1016/j.geothermics.2012.10.005.

Witte, H.J.L. 2013. Error Analysis of Thermal Response Tests. Applied Energy 109: 302-11. doi:10.1016/j.apenergy.2012.11.060.

Witte, H.J.L., G. van Gelder and J.D. Spitler. 2002. In-Situ Thermal Conductivity Testing: A Dutch Perspective. ASHRAE Transactions 108(1): 263-72. 